\title{
HUBUNGAN ANTARA CITRA TUBUH DAN HARGA DIRI PADA REMAJA AKHIR PENYANDANG CACAT TUNA DAKSA
}

\author{
Yudhi Prasetya Wicaksono Abdussamad dan Ratna Supradewi \\ Fakultas Psikologi Universitas Islam Sultan Agung Semarang
}

Email: supradewi@unissula.ac.id

\begin{abstract}
Abstrak
Penelitian ini bertujuan untuk mengetahui hubungan antara citra tubuh dan harga diri pada remaja akhir penyandang cacat tuna daksa yang berada di Balai Besar Rehabilitasi Sosial Bina Daksa (BBRSBD) Prof. Dr Soeharso Surakarta. Penelitian ini menggunakan metode kuantitatif. Subjek dalam penelitian ini adalah remaja akhir penyandang cacat tuna daksa yang berjumlah 50 orang. Metode pengambilan sampel yang digunakan yaitu teknik sampel jenuh. Alat ukur yang digunakan dalam penelitian ini terdiri dari 2 skala, yaitu skala citra tubuh dan skala harga diri. Skala citra tubuh terdiri dari 26 aitem pernyataan, koefisisen korelasi skor bergerak dari $0.333-0.795$ dengan reliabilitas 0.934 . Skala harga diri terdiri dari 35 aitem pernyataan, koefisien korelasi skor aitem total bergerak dari 0.339 - 0.744 dengan reliabilitas 0.935 Hasil penelitian menunjukan bahwa ada hubungan yang sangat signifikan antara citra tubuh dengan harga diri pada remaja akhir penyandang cacat tuna daksa, yaitu diketahui $r x y=0,712$ dengan $p=0,000(p<0,01)$. Sumbangan efektif citra tubuh terhadap harga diri sebesar $50.8 \%$ sedangkan $49.2 \%$ merupakan kontribusi dari faktor-faktor lain. Analisis data menggunakan analisis product moment.
\end{abstract}

Kata kunci : citra tubuh, dan harga diri

\section{THE RELATIONSHIP BETWEEN BODY IMAGE AND SELF ESTEEM AT THE ADOLESCENT WITH PHYSICAL DISABILITY}

\begin{abstract}
This research aims to investigate the relationship between body image and self esteem at the adolencent with physical disability in Balai Besar Rehabilitasi Sosial Bina Daksa (BBRSBD) Prof. Dr. Soeharso Surakarta. This research uses quantitative method. The subject of the research are the adolencent with physical disability which has 50 person. The method used in getting the sample is population study technique. The instrument used in this research belongs two scales those are body image and self esteem scale. The body image scale has 26 items of statements, the coefficient correlation score starts from $0.333-0.795$ with the reliability 0.934 . The scale of self esteem belongs to 35 items of statements, coefficient score total items start from $0.339-0.744$ with the reliability 0.935 . The result of the research shows that there is a significant relationship between body image with self esteem towards the adolencent with physical disability, that is $r x y=0,712$ with $p=0.000$ ( $p$ $<0,01)$. The effective effect of body image towards self esteem is $50.8 \%$ while $49.2 \%$ are contributed from other factors. The analysis of the data uses product moment analysis.
\end{abstract}

Keywords: body image and self esteem

\section{Pendahuluan}

Setiap manusia yang berada di dunia pasti ingin mengharapkan memiliki bentuk tubuh yang normal dan baik sehingga individu tersebut mampu melakukan seluruh aktifitas yang mereka dapat lakukan sebagaimana manusia lainya. Tetapi tidak semua manusia di dunia terlahir dengan memiliki bentuk tubuh atau kondisi yang baik dan membuat individu tersebut tidak mampu melakukan 
Hubungan Antara Citra Tubuh dan Harga Diri Pada Remaja Akhir

Penyandang Cacat Tuna Daksa

Proyeksi Vol. 13 (1) 2018, 98-108

aktifitas yang mereka dapat lakukan serta menghambat tugas-tugas perkembangan yang seharusnya dapat dilaksanakan.

Masa remaja adalah masa peralihan atau transisi dari kanak kanak ke masa dewasa. Dimasa remaja, individu tersebut mengalami perubahan, baik secara fisik serta psikisnya. Salah satu tugastugas perkembangan yang dijelaskan oleh Hurlock (1980) yaitu remaja harus menerima keadaaan fisik yang dimiliki dan menggunakan tubuhnya secara afektif. Remaja tersebut diharapkan mampu merasa bangga dan puas dengan keadaan tubuh serta fisik yang dimiliki, sehingga mampu melindungi tubuhnya secara efektif. Tugas perkembangan tersebut akan terasa sulit dicapai jika hal tersebut dihadapkan pada remaja yang memiliki kondisi fisik yang tidak normal atau cacat fisik.

Berdasarkan data yang dikeluarkan oleh kementrian sosial, bahwa jumlah masyarakat Indonesia yang menyandang cacat fisik di Indonesia sebanyak 717.312 jiwa atau dengan presentasi sebanyak 33,74\% masyarakat. Jawa Tengah sendiri telah menjadi provinsi dengan penyandang cacat fisik terbanyak kedua di Indonesia. (DEPKES, 2014).

Salah satu bentuk ketidaknormalan fisik adalah tuna daksa atau yang disebut cacat fisik. Khabibah (2014) menambahkan bahwa keterbatasan fisik yang diderita oleh penyandang tunadaksa secara langsung ataupun tidak akan mengakibatkan munculnya berbagai masalah psikologis, salah satunya harga diri yang rendah. Penyandang tunadaksa biasanya mudah merasa cemas, menarik diri dari lingkungan, dan bersikap apatis serta menjadi tergantung dengan orang lain.

Masyarakat bertanggung jawab atas reaksi negative yang diberikan kepada penyandang cacat yang menyebabkan mereka mengalami masalah emosional. Hal tersebut membuat penyandang cacat memiliki harga diri rendah. Ditandai dengan perasaan bersalah, rasa malu, ketidak berdayaan, penarikan diri dari lingkungan, dan merasa tidak berdaya Cusforth (Omolayo, 2009).

Miryana dan Piek (2006) menjelaskan umumya anak-anak dan remaja yang memiliki cacat fisik menganggap diri mereka kurang kompeten, tidak hanya dalam kemampuan fisik tetapi juga dalam hal penampilan fisiknya serta kehidupan sosial mereka. Individu yang mengalami cacat memiliki masalah dalam menyesuaikan dengan masyarakat, karena label yang diberikan bahwa penyandang cacat tidak sama dengan individu yang normal.

Rendahnya harga diri dimiliki yang dimiliki penyandang cacat fisik ( tuna daksa ) akan berpengaruh terhadap kemampuan individu tersebut didalam malakukan sosialisi serta berinteraksi terhadap lingkungan sekitar ataupun didalam pergaulan sehari-hari. Penyandang tuna daksa memiliki kecenderungan hidup didalam lingkungan mereka sendiri, dengan perasaan dan sikap-sikap negatif yang dimiliki, serta rasa rendah diri. Kesulitan individu yang memiliki cacat tubuh didalam berinteraksi dan melakukan hubungan sosial dikarenakan mereka beranggapan memiliki bentuk tubuh yang kurang menarik sehingga mempersulit mereka didalam menyesuaikan diri dengan kehidupan sosial (karyanta, 2013).

Cash and Pruzinsky (Nurvita \& Handayani, 2015) menjelaskan salah satu faktor yang mempengaruhi perkembangan harga diri seseorang yaitu citra tubuhs. Citra tubuh menurut Perucha dkk (2015) adalah sikap dan penilaian seseorang mengenai bentuk tubuhnya sendiri, baik itu penilaian buruk atau penilaian yang baik mengenai tubuhnya, baik itu dilakukan secara sadar maupun tidak sadar.

Seseorang dengan citra tubuh yang baik akan selalu memandang positif dirinya, merasa nyaman terhadap keadaan yang dimilikinya senang dengan dirinya bagaimanapun bentuk dan keadaanya saat ini. Sedangkan seseorang dengan citra tubuh yang buruk akan merasa tidak percaya 
diri, selalu merasa minder dengan keadaan yang dimiliki, cenderung mudah emosi dan tidak bisa menerima keadaan dirinya yang dimiliki (Romansyah \& Natalia, 2012).

Penelitian yang dilakukan oleh Clay dkk (2005) menunjukan bahwa terdapat hubungan antara citra tubuh dan harga diri pada remaja putri, penelitian tersebut menghasilkan bahwa remaja putri yang memiliki citra tubuh yang rendah akan menyebabkan harga dirinya menjadi rendah. Begitu sebaliknya, remaja putri yang memiliki citra tubuh tinggi akan manyebabkan harga dirinya menjadi tinggi. Penelitian yang dilakukan Nurvita dan Handayani (2015) pada remaja yang mengalami obesitas, menunjukan bahwa terdapat hubungan yang signifikan antara citra tubuh dan harga diri. Penelitian tersebut ditemukan bahwa Harga diri di sini sangat berperan penting terhadap perkembangan citra tubuh yang dimiliki oleh remaja yang mengalami obesitas.

\section{Harga diri}

Harga diri merupakan suatu proses dalam mengevaluasi diri individu terhadap kualitas kualitas yang ada di dalam dirinya sendiri dan terjadi secara terus menerus di dalam diri manusia(Christia, 2007). Harga diri juga merupakan kumpulan komponen kognitif, afektif, dan evaluasi yang bukan hanya masalah persoalan psikologis ataupun pribadi, tetapi juga interaksi sosial.

Murk(2006) menjelaskan bahwa harga diri adalah sikap yang dimiliki individu baik itu bersifat positif ataupun bersifat negatifterhadap diri individu itu sendiri.Lubis (Syafitri, 2014) menjelaskan bahwa harga diri ialah penilaian individu terhadap dirinya sendiri.Penilaian tersebut menyatakan sikap seberapa besar individu tersebut percaya pada dirinya bisa atau mampu, berharga, dan berhasil menurut nilai serta keahlian pribadinya.

Garden(Mulyana \& Santi, 2010) mengatakan bahwa harga dirimerupakan suatu pandangan atau penilaian individu mengenai keberhargaan. Harga dirimerupakan suatu ciri yang terus berubah secara aktif dan bukan merupakan sesuatu yang secara tiba-tiba berganti dari situasi satu kesituasi yang lainya.

Coopersmith (1967) juga menambahkan harga diri adalah suatu evaluasi mengenai diriyang dilakukan individu yang dinyatakan dalam bentuk menerima ataupun menolak dari sejumlah penghargaan, perhatian yang diterima individu itu sendiri dari lingkungan sekitarnya.Desiningrum(2012) menjelaskan bahwa harga dirimerupakan suatu dimensi dari kepribadian yang menunjukan penilaian individu itu sendiriterhadap dirinya dan sejauh mana individu itu menghargai dirinya.

Burn(Sari, 2012) menjelaskan terdapat lima faktor yangdapat mempengaruhiharga diri seseorang, antara lain:

\section{a. Pengalaman}

Merupakan perasaan, emosi, kejadian serta tindakan yang pernah terjadi atau dialami oleh individu yang dianggap bermakna atau meninggalkan kesan dalam diri inidvidu.

b. Pola asuh

Individu yang memiliki pola asuh yang baik serta keluarga yang bahagia akan memiliki harga diri yang yang tinggi, karena adanya penerimaan, dukungan orang tua, cinta dari mereka. Sedangkan orang tua yang sering memberikan hukuman serta larangan yang tidak jelas alasannya, maka akan merasa tidak berharga.

c. Lingkungan 
Pembentukan harga diri inidividu itu merupakan proses hasil dari lingkungannya. Individu itu merasa dihargai atau tidak, berharga atau tidak, semua itu merupakan hasil dari lingkungan.

\section{d. Ekonomi}

Status sosial ekonomi ialah hal yang mendasari individu berbuat untuk memenuhi dorongan sosial yang membutuhkan dukungan financial serta mempengaruhi kebutuhan sehari hari.

\section{e. Citra tubuh}

Manusia yang memiliki kondisi fisik yang baik, lebih cenderung meniliki harga diri lebih baik dibandingkan dengan individu yang memiliki kondisi fisik kurang menarik. Begitupun bagi individu yang sangat memikirkan masalah bentuk serta ukuran tubuhnya.

Falker(Pambudhi, Suroso, \& Tatik, 2015) menjelaskan bahwa terdapat tiga aspek harga diri yaitu ;

a. Perasaan diterima (Felling Of Belonging)

Perasaan diterima merupakan perasaan yang dirasakan oleh individu bahwa dirinya diterima oleh anggota kelompok.Kelompok disini dapat berupa keluarga, teman sebaya, atapun kelompok apapun. Individu akan menilai positif mengenai dirinya bila merasa dirinya diterima oleh anggota kelompok. Namun, individu akan menilai negatifdirinya bila menglami perasaan tidak diterima.

b. Perasaan Mampu (Felling Of Competence)

Perasaan mampu merupakan keyakinan dan perasaan yang dimiliki oleh individu terhadap kemampuan yang ada pada dirinya didalam mencapai sesuatu hasil yang diharapkan. Individu tersebut akan berusaha dengan keterbatasan yang dimilikinyaa dengan baik.

c. Perasaaan Berharga (Felling Of Worth)

Perasaan yang dirasakan individu, dimana individu tersebut merasa bahwa dirinya berharga dan bernilai atau tidak.Perasaan tersebut biasanya banyak dipengaruhi oleh pengalaman yang terjadi dimasa lalu. Individu yang merasa dirinya tersebut berharga akan dapat mengontrol prilaku yang dimiliki terhadap lingkungan sekitarnya.

Menurut Clemes(2001)harga diri terbagi menjadi dua bentuk karakteristik, anatar lain :

a. Individu dengan harga diriyang rendah, adapun karakteristik yang dimiliki natara lain:

a). Karakteristik fisik, inidvidu yang memiliki harga diri yang rendah cenderung memiliki kurang bersemangat, gugup serta tegang, tidak mampu menatap mata orang lain, sikap tubuh yang cenderung membungkuk, jabat tangan yang lemah dan dahi yang mengkerut.

b). Karakteristik emosional; individu yang memiliki harga diri rendah cenderung pemalu, suka menunda-nunda, tidak mau mengakui kesalaha yang telah diperbuat, cemderung agresif, angkuh dan suka mengkeritik orang lain.

c).Karakteristik Psikis; individu dengan harga diri rendah cenderung mudah merasa cemas, menolak diri sendiri, ingin disukai dan diterima oleh setiap orang, mudahmerasa bersalah serta penuh penyesalah didalam hidupnya,gampang putus asa dan menganggap dirinya kalah. 
b. Individu yang memiliki harga diritinggi, adapaun karakteristik yang dimiliki antara lain:

a). Fisik; individu cenderung berpenampilan rapi, suara yang mantap, dan mampu menatap mata orang lain yang diajak berkomunikasi.

b). Emosional; dari segi emosional indvidu yang memiliki harga diri tinggi mampu mentoleransi frustsi yang dialami dengan baik, dan penuh semangat didalam menghadapi dan menerima tantangan-tantangan baru.

c). Psikis; Individu yang memiliki haragdiri tinggi cenderung mamu bertindak secara mendiri, mampu mempengaruhi orang lain, merasa dirinya berarti bagi orang lain, mempunyai tujuan didalam hidup, dan merasa bangga atas prestasi yang telah diraih.

\section{Citra tubuh}

Widiatun (Prameswari, Aisah, \& Mifbakhuddin, 2013) menjelaskan bahwa citra tubuh merupakan sikap individu mengenai tubuhnya secara sadar maupun tidak sadar. Sikap tersebuh berupa persepsi dan perasaan individu mengenai ukuran dan bentuk tubuhnya, fungsi dari penampilannya, serta mengenai potensi tubuh ini kedepannya,saat ini, dan di masa lalu.

Honigam dan castel(Januar \& Putri, 2007), mengatakan bahwa citra tubuh merupakan gambaran mental individu mengenai bentuk dan ukuruan tubuh yang dimilikinya, bagaimana individu tersebut memberikan persepsi serta memberikan penilaian terhadap apa yang dipikirkan ataupun dirasakan terhadap bentuk serta ukuran tubuh yang dimiliki, dan penilaian orang lain terhadap dirinya.

Citra tubuh menurut Papalia (2014) merupakan suatu keyakinan deskriptif dan evaluativ yang dimiliki seseorang, mengenai bentuk tubuh atau penampilan dirinya.Citra tubuhmenurut Perucha dkk (2013) adalah sikap dan penilaian seseorang mengenai bentuk tubuhnya sendiri, baik itu penilaian buruk atau penilaian yang baik mengenai tubuhnya, baik itu dilakukan secara sadar maupun tidak sadar.

Cash(Blashill \& Wilhelm, 2013), menjelaskan bahwa citra tubuh merupakan gambaran mengenai bentuk tubuh yang dimiliki yang terdiri dari beberapa komponen, yaitu sikap, persepsi dan perasaan mengenai tubuh yang dimiliki. Santrock(2013) menenjelaskan bahwa citra tubuh ialah bagaimana seseorang itu menilai atau mempersepsikan penampilan dan fisiknya, serta bagaimana individu tersebut dilihat oleh orang lain.

Hoyt ( $\mathrm{Na}^{\prime} i m a h$ \& Rahardjo, 2008) menjelaskan bahwa citra tubuhmerupakan suatu sikap individu terhadap tubuh yang dimiliki, baik dari segi ukuran, bentuk tubuh maupun keindahan berdasarkan hasil evaluasi individu tersebut dan pengalaman mengenai fisiknya.Pembentukancitra tubuh sendiri dipengaruhi oleh persepsi, imajinasi, emosi ataupun suasana hati dan pengalaman fisik individu.

Menurut Thompson (Januar \& Putri, 2007) ada beberapa faktor yang mempengaruhi citra tubuh antara lain :

a. Pengaruh berat badan atau persepsi kurus/gemuk

Keinginan individu untuk menjaga berat badan tetap ideal dengan menjaga pola makan secara teratur, sehingga menimbulkan persepsi mengenai citra tubuh yang baik dan akan sesuai dengan yang diinginkan.

b. Siklus Hidup 
Pada dasarnya jika dimasa lalu individu memiliki bentuk tubuh yang ideal maka akan timbul keinginan untuk kembali ke masa lalu.

c. Budaya

Pengaruh lingkungan sekitar individu dan budaya yang mempengaruhi mengenai norma-norma mengenai penampilan fisik serta ukuran tubuh yang menarik.

d. Sosialisasi

Munculnya pengaruh dari teman sebaya yang mengakibatkan individu ikut terpengaruh didalamnya.

\section{e. Peran gender}

Orang tua menjadi sosok penting dalam citra tubuh yang dimiliki individu, mengakibatkan individu lebih mudah dan cepat terpengaruh.

\section{f. Konsep diri}

Gambaran individu mengenai dirinya sendiri, termasuk penilaian sosial dan penilaian diri.

g. Pengaruh distorsi citra tubuh pada diri individu

Persepsi atau pandangan individu yang buruk terhadap tubunnya yang mengakibatkan diiukuti timbulnya sikap yang buruk.

Altabe dan Thomson(1993)menjelaskan bahwa citra tubuh atau citra tubuhberkaitan dengan tiga komponen, antara lain sebagai berikut :

a. Komponen Persepsi

Komponen persepsi dalam citra tubuh disini berhubungan dengan bagaimana individu didalam mempersepsikan dan memandang penampilan dirinya.Penampilan tersebut dapat berupa bentuk fisik ataupun ukuran tubuhnya.

b. Komponen Sikap

Sikap disini lebih berhubungan dengan kepuasan individu terhadap tubuh yang dimiliki, perhatian individu terhadap tubuhnya dan kecemasan individu terhadap penampilan tubuhnya.

c. Komponen Prilaku

Prilaku pada citra tubuh disini lebih berkaitan pada penghindaran terhadap situasi yang menyebapkak individu mengalami ketidaknyamanan yang berhubungan dengan penampilan fisik yang dimiliki.

Romansyah dan Natalia (2012)menjelaskan bahwa citra tubuh dibagi menjadi 3 bentuk atau kriteria antara lain, sebagai berikut :

a. Citra tubuh baik

Individu yang memiliki citra tubuh yang baik atau positif, adalah pribadi yang selalu memandang positif dirinya, merasa nyaman terhadap keadaan yang dimilikinya, senang dengan dirinya bagaimanapun bentuk dan keadaannya saat ini.

b. Citra tubuh sedang

Individu yang memiliki citra tubuh yang sedang atau cukup, merupakan yang individu yang masil labil dan masih ragu-ragu didalam menilai dirinya sendiri. Individu terkadang merasa nyaman dengan tubuh yang ia miliki, dan terkadang mereka juga merasa kurang nyaman dengan dirinya. Namun, individu yang memiliki citra tubuh yang cukup masih bisa menerima keadaan yang dimiliki dengan baik. 
c. Citra tubuh buruk

Individu yang memiliki citra tubuh yang buruk,merupakan individu individu yang tidak percaya diri, selalu merasa minder dengan keadaan yang dimiliki, cenderung mudah emsi dan tidak bisa menerima keadaan dirinya yang dimiliki sehingga individu yang memiliki citra tubuh yang buruk cenderung menarik diri.

\section{Metode penelitian}

Penelitian ini terdiri dari 2 variabel yaitu variabel bebas (citra tubuh) dan satu variabel tergantung (harga diri). Populasi yang digunkan dalam penelitian ini yaitu remaja akhir penyandang cacat tuna daksa di Balai Besar Rehabilitasi Sosial Bina Daksa (BBRSBD) Prof. Dr. Soeharso Surakarta. Sampel yang digunakan alam penelitian ini adalah remaja akhir penyandang cacat tuna daksa. Jumlah sampel dalam penelitian ini adalah 50 orang. Teknik pengamblan sampel yang digunakan adalah sampel jenuh.

Metode pengumpulan data yang digunakan adalah skala psikologi. Skala dalam penelitian ini terdiri dari dua skala yaitu skala citra tubuh dan skala harga diri. Skala citra tubuh disusun berdasarkan aspek yang ada dalam citra tubuh yaitu : komponen persepsi, komponen sikap dan komponen prilaku. Skala citra tubuh terdiri dari 26 aitem, koefisien korelasi skor bergerak dari 0.333 -0.795 dengan reliabilitas 0.934 . Skala harga diri disusun berdasarkan aspek yang ada dalam harga diri yaitu: perasaan diterima (Feeling Of Belonging), perasaan Mampu (Feeling Of Competence), dan yang terakhir perasaan berharga (Feeling Of Worth). Skala harga diri terdiri dari 35 aitem, koefisien korelasi skor aitem bergerak dari 0.339-0.744 dengan 0.935. Berikut sebaran aitem berdaya beda rendah dan tinggi :

Distribusi Aitem Daya Beda Tinggi Dan Daya Beda Rendah Skala Harga diri

\begin{tabular}{|c|c|c|c|c|}
\hline \multirow{2}{*}{ No } & \multirow{2}{*}{ Aspek } & \multicolumn{2}{|c|}{ Aitem } & \multirow{2}{*}{ Jumlah } \\
\hline & & $\mathbf{F}$ & UF & \\
\hline 1. & Perasaan Diterima & $\begin{array}{c}1,7,13 \\
19^{*}, 25,31\end{array}$ & $\begin{array}{l}4,10,16 \\
22,28,34\end{array}$ & 12 \\
\hline 2. & Perasaan Mampu & $\begin{array}{l}5,11,17 \\
23,29,35\end{array}$ & $\begin{array}{c}2,8,14 \\
20,26,32\end{array}$ & 12 \\
\hline 3. & Perasaan Beharga & $\begin{array}{c}3,9,15 \\
21,27,33\end{array}$ & $\begin{array}{c}6,12,18 \\
24,30,36\end{array}$ & 12 \\
\hline & Jumlah & 18 & 18 & 36 \\
\hline \multicolumn{4}{|c|}{ Ket $: *$ Aitem berdaya rendah } & Sebaran Nomer Aitem Skala Citra tubuh \\
\hline \multirow{2}{*}{ No } & \multirow{2}{*}{ Aspek } & \multicolumn{2}{|c|}{ Aitem } & \multirow{2}{*}{ Jumlah } \\
\hline & & $\mathbf{F}$ & UF & \\
\hline 1. & Komponen Persepsi & $\begin{array}{l}1,7,13 \\
19,25^{*}\end{array}$ & $\begin{array}{c}4,10,16^{*} \\
22,28\end{array}$ & 10 \\
\hline 2. & Komponen Prilaku & $\begin{array}{c}5,11,17 \\
23,29\end{array}$ & $\begin{array}{c}2,8,14 \\
20,26\end{array}$ & 10 \\
\hline 3. & Komponen Sikap & $\begin{array}{c}3,9 *, 15 \\
21,27\end{array}$ & $\begin{array}{c}6^{*}, 12,18 \\
24,30\end{array}$ & 10 \\
\hline & Jumlah & 15 & 15 & 30 \\
\hline
\end{tabular}


Ket : *Aitem berdaya beda rendah

Perhitungan uji daya beda aitem menggunakan product moment. Pengujian reliabilitas dalam penelitian ini menggunakan uji koefisiesnsi reliabilitas alpha cronbach dengan bantuan SPSS 16.0 for windows.

Hasil

Uji Asumsi

a. Uji Normalitas

Uji normalitas dilakukan untuk mengetahui apakan populasi data memiliki distribusi yang normal atautidak.Dari data yang variabel penelitian diuji normalitasnya sebarannya dengan teknik One-Sample Kolmogorov-Smirnov Tes dengan taraf signifikansi 0.05. Data yang dinyatakan memiliki distribusi normal jika signifikansi lebih besar dari 5\% atau 0.05 Berdasarkan hasil perhitungan uji normalitas yang telah dilakukan peneliti terhadap 2 variabel penelitian diperoleh nilai KS-Z sebagai berikut:

\section{Hasil Uji Normalitas}

\begin{tabular}{ccccccc}
\hline Variabel & Mean & $\begin{array}{c}\text { Std. } \\
\text { Deviasi }\end{array}$ & KS-Z & Sig & P & Keterangan \\
\hline Harga diri & 108,5000 & 12,86706 & 0,880 & 0,420 & $\geq 0,05$ & Normal \\
Citra tubuh & 78,3400 & 11,87625 & 0,513 & 0,955 & $\geq 0,05$ & Normal \\
\hline
\end{tabular}

Hasil uji normalitas pada kedua variabel menunjukan bahwa nilai KS-Z yang diperoleh masing-masing variabeldiatas 0,05 Maka dapat disimpulkan kedua data tersebut memiliki distribusi normal.

b. Uji Linearitas

Uji lineraitas digunakan untuk mengetahui apakah terdapat hubungan yang linear pada masing masing dari variabel-variabel penelitian atau tidak. Uji lineraitas dilakukan dengan menggunkan SPSS for windows release 16.

Hasil dari uji linearitass antara variabel harga diriterhadap variabel citra tubuhmenunjukan hasil nilai $\mathrm{F}$ linear sebesar 49,472 dengan taraf signifikansi $p=0,000(p$ $\leq$ 0.05), hasil tersebut menunjukan bahwa variable harga diridan variable citra tubuhmemiliki hubungan secara linear.

\section{Uji Hipotesis}

Berdasarkan hasil pengujian korelasi antara citra tubuhdanharga diri diperoleh bahwa rxy $=0,712$ dengan nilai signifikansi sebesar $0,000(p<0,01)$. Hasil yang diperoleh menunjukkan bahwa terdapat hubungan positif yang sangat signifikan antara citra tubuhdengan harga diripada remaja akhir penyandang cacat tuna daksa di BBRSBD Prof. Soeharso Surakarta. Hal ini menunjukan bahwaa hipotesis dalam penelitian ini diterima. 


\section{Pembahasan}

Tujuan dari penelitian ini adalah untuk menguji apakah terdapat hubungan anatara citra tubuh dan harga diri pada remaja akhir penyandang cacat tuna daksa di BB-RSBD Surakarta Solo. Hasil uji hipotesis pada penelitian ini menunjukan nilai korelasi $r x y=0,712$ dengan taraf signifikansi sebesar $0,000(p<0,01)$. Hal tersebut menunjukan terdapat hubungan positif yang sangat siginifikan antara citra tubuh dan harga diri pada remaja akhir penyandang cacat tuna daksa di BB-RSBD Surakarta.

Penelitian yang dilakukan oleh Herabadi (2007) menunjukan bahwa harga diri seseorang sangatlah bergantung terhadap bagaimana individu tersebut mengevaluasi dan berfikir terhadap tubuh yang dimiliki secara subjektif. Semakin terbiasa individu tersebut meiliki pemikian yang positif mengenai tubuh yang dimiiki maka individu tersebut juga akan memiliki harga diri yang lebih tinggi.

Santrok (2013) bahwa penampilan fisik sangat berkontribusi didalam membentuk harga diri yang dimiliki oleh remaja. Penampilan fisik menjadi salah satu komponen bagi orang lain untuk menilai individu tersebut. Salah satu bagian dari citra tubuh adalah penampilan fisik yang dimiliki individu, sehingga keadaan citra tubuh yang dimiliki dapat mempengaruhi harga diri yang dimiliki oleh remaja. Citra tubuh juga dijelaskan memiliki peran pengaruh bagi harga diri remaja. Harga diri yang tingi yang dimiliki remaja berkaitan dengan gambaran positif yang dimiliki oleh mengenai tubuh yang dimiliki dan sebaliknya individu yang memiliki gambaran negatif serta ketidak puasan terhadap tubuh yang dimiliki akan berpengaruh terhadap rendahnya harga diri yang dimiliki oleh remaja tersebut (Rahmawati dan yuniar, 2012).

Hasil penelitian yang dilakukan ( Gatti dkk, 2014) menjelaskan bahwa citra tubuh memiliki hubungan yang erat dengan harga diri para remaja. Harga diri pada remaja dapat dicapai dengan mengikuti bagaimana remaja tersebut memiliki kepuasan terhadap dirinya. Remaja yang puas terhadap tubuh yang dimiliki dapat mencapai harga diri yang baik begitupun sebaliknya.

Hasil analisis dalam penelitian ini menunjukan bahwa citra tubuh dan harga diri pada remaja akhir penyandang cacat tuna daksa berada pada kategori tinggi 108,5. Skor mean empirik pada harga diri berada dalam kategori tinggi yaitu. Sedangkan mean empirik skor pada citra tubuh berada dalam kategori tinggi yaitu 78,34 . Sumbangan efektif citra tubuh terhadap harga diri adalah 0,508 . Nilai tersebut menjelaskan bahwa citra tubuh memberikan kontribusi terhadap harga diri sebesar 50,8\% sedangkan 49,2\% merupakan kontribusi dari faktor- faktor lain.

\section{Kesimpulan}

Berdasarakan hasil dari analisis data dan pembahasan yang telah dilakukan maka dapat disimpulkan bahwa citra tubuh dan harga diri memiliki koefisien korelasi $r_{\mathrm{xy}}=0,712$ dengan nilai signifikansi sebesar 0,000 $(p<0,01)$. Hasil tersebut menunjukan bahwa terdapat hubungan positif yang signifikan antara citra tubuh dan harga diri pada remaja akhir penyandang cacat tuna daksa. Hipotesis yang diajukan peneliti diterima, yaitu semakin tinggi citra tubuh maka semakin tinggi harga diri pada remaja akhir penyandang cacat tuna daksa. 


\section{Saran}

\section{Bagi Remaja}

Bagi remaja penyandang cacat tuna daksa di BBRSBD Prof. Dr. Soeharso Surakarta, disarankan agar citra tubuh yang telah dimiliki dipertahankan, sehingga dapat meningkatkan harga diri yang dimiliki.

\section{Bagi Institusi}

Bagi instansi yang terkait disarankan untuk lebih bayak membuat program-program pembinaan-pembinaan seperti pelatihan untuk meningkatkan citra tubuh agar lebih menyukai tubuh yang dimiliki saat ini, sehingga meningkatkan harga diri para penyandang cacat tuna daksa yang berada di Balai Besar Pusat Rehabilitasi Sosial Bina Daksa (BBRSBD) Prof. Dr. Soeharso Surakarta.

\section{Peneliti selanjutnya}

Bagi peneliti selanjutnya diberikan saran agar memakai sampel penelitian yang lebih banyak serta dapat membedakan sabjek penelitian yang cacat fisik sejak lahir serta cacat fisik akibat kecelakaan atau sakit.

\section{Daftar pustaka}

Altabe, M., \& Thompson, J. K. (1993). Body image changes during. Internation Journal of Eating Disorders , 13 (3), 323-328.

Christia, M. (2007). Inner voice dan self-esteem. Sosial Humaniora , 11 (1), 37-41.

Clay, D., Vignoles, V. L., \& Dittmar, H. (2005). Body image and self-esteem among adolescent girls: testing the influence of sociocultural factors. Journal of Research on Adolescence , 15(4), 451-477.

Coopersmith, S. (1967). The Antecedent of self esteem. San Francisco: W..H Freeman and Company.

DEPKES, R. (2014, Desember 3). Pusdating. Retrieved April 3, 2016, from Infondation Disabilitas: hppt://www.depkes.go.id/resources/download/pusdatin/infondation/infondation_disa bilitas.pdf

Gatti, E., Linio, C., Traficante, D., \& Confalonieri, E. (2014). I like my body; therefore, i like myself": How body image influences self-esteem a cross-sectional study on italian adolescents. Europe's Journal of Psychology , 10(2), 301-317.

Herabadi, A. D. (2007). Hubungan antara kebiasaan berfikir negatif tentang tubuh dengan body esteem dan harga diri. Sosial Humaniora , 11(1), 18-23.

Hurlock, E. B. (1980). Psikologi perkembangan; Suatu pendekatan sepanjang rentan kehidupan. Jakarta: Erlangga.

Karyanta, N. A. (2013). Harga diri pada penyandang tuna daksa. Jurnal Psikologi , 5(9), 1-18.

Khabibah, S. S. (2014). Pengaruh pelatihan diri terhadap peningkatan kebermaknaan hidup remaja tunadaksa karena kecelakaan. Jurnal Candra Jiwa , 3(1), 53-63.

Miyahara, M., \& piek, J. (2006). Self esteem of children and adolescents. Journal of Developmental and Physical Disabilities , 18(3), 219-234.

Murk, C. J. (2006). Self esteem research, theory, and practice: toward a positive psychology of self esteem . New York: Springer Publisher Company. 
Na'imah, T., \& Rahardjo, P. (2008). Pengaruh komparasi sosial pada public figure dimedia massa terhadap citra tubuh remaja di kecamatan Patikraja, kabupaten Banyumas. Humaniora, 9 (2), 165-178.

Nurvita, V., \& Handayani, M. M. (2015). Hubungan antara self-esteem dengan body image pada remaja awal yang mengalami obesitas. Jurnal Psikologi Klinis dan Kesehatan Mental , 4(1), 41-49.

Omolayo, B. (2009). Self-esteem and self-motivational needs off. Journal of Alternative Perspectives in the Social Sciences , 1(2), 449-458.

Pambudhi, Y. A., Suroso, \& Tatik, M. (2015). Efektivitas group cognitive behavior therapy dalam menurunkan kecemasan menghadapi prilaku bullying ditinjau dari harga diri pada korban bullying. Jurnal Ilmiah Psikologi Terapan , 3 (1), 18-31.

Papalia, D. E. (2014). Menyelami perkembangan manusia. Jakarta: Salemba Humanika.

Perucha, S., Pramewasti, I., \& Mifbakhuddin, S. A. (2013). Hubungan obesitas dengan citra tubuh dan harga diri pada remaja putri di kelurahan Jomblang ecamatan Candisari Semarang. Jurnal Keperawatan komunitas , 1(1), 52-61.

Rahmania, \& Yuniar, I. (2012). Hubungan antara self esteem dengan kecenderungan body dysmorphic disorder pada remaja putri. Jurnal Psikologi Klinis dan Kesehatan Mental , 1 (2), 102-109.

Romansyah, M., \& Natalia, D. (2012). Gangguan Cctra tubuh di hubungkan dengan aktivitas olahraga pada mahasiswa obesitas. Jurnal STIKES , 5 (2), 203-212.

Santrok, J. W. (2013). Adolescence. New York: Mc Graw Hill Education.

Sari, D. N. (2012). Hubungan antara body image dan self esteem pada dewasa awal tuna daksa. Jurnal Ilmiah Mahasiswa, , 1(1).1-9. 